DOI: 10.34015/2523-4552.2021.2.07

УдК 355.9

Пирожик О. В., радник першого заступника голови Волинської обласної ради, депутат Волинської обласної ради ORCID: 0000-0001-5793-7433

\title{
ПРО НЕОБХІДНІСТЬ ВИКОРИСТАННЯ УКРАЇНОЮ ПОЗИТИВНОГО ДОСВІДУ США $З$ ПИТАНЬ РОЗБУДОВИ СИСТЕМИ ІНФОРМАЦІЙНОЇ БЕЗПЕКИ
}

У статті розглянуті питання, пов'язані з необхідністю створення в Україні ефективної національної системи забезпечення інформаційної безпеки держави за зразком такої країни, НАТО, як США. Зокрема, проаналізовано нормативно-правові акти США у цій сфері суспільних відносин та позитивний досвід з означених питань, а також запропоновані науково обгрунтовані заходи щодо вирішення означеної проблематики.

Ключові слова: інформаційна безпека; інформаційна війна; національна безпека; система; забезпечення; кібербезпека.

В данной статье рассмотрены вопросы, связанные с необходимостью создания в Украине эффективной национальной системы обеспечения информационной безопасности государства по образцу такой страны НАТО, как США. В частности, проанализированы нормативно-правовые акты США в этой сфере общественных отношений и положительный опыт по указанным вопросам, а также предложены научно обоснованные меры по решению обозначенной проблематике.

Ключевые слова: информационная безопасность; информационная война; национальная безопасность; система; обеспечения; кибербезопасность.

Постановка проблеми. Як показує практика, торкаючись питання формування системи забезпечення інформаційної безпеки в Україні, неможливо обійти увагою зарубіжний досвід країн НАТО, які мають у цій сфері ту ж системну проблему, що й Україна, - необхідність запобігання та протидії інформаційній агресії та інформаційним війнам зі сторони Російської Федерації (РФ). При цьому, результати проведеного аналізу наукових та інших джерел свідчить про те, що навіть в одного з фундаторів НАТО Сполучених Штатів Америки (США) ця проблема ставиться на друге місце після тероризму і розглядається як загроза національній безпеці нації.

Загалом, інформаційна безпека - поняття, введене у науковий обіг доволі давно, проте особливої актуальності воно набуло із розвитком технологій. Якщо узагальнити доктринальні підходи з означеного пи- 
тання, можна зробити висновок, що поняття «інформаційна безпека» слід розглядати на основі комплексного або інтегрального підходу як стан та процес захищеності життєво важливих інтересів особи, суспільства та держави, при якому вона, з одного боку, здатна ефективно протистояти дестабілізуючому та неправомірному впливу зовнішніх і внутрішніх інформаційних загроз, а 3 іншого - iї постійне функціонування не створює інформаційних загроз для елементів самої системи і зовнішнього середовища. Відтак, можна констатувати, що інформаційна безпека - це стан захищеності інформації в системах і додатках, при якому зберігається цілісність та конфіденційність даних, а також їх стійкість до зовнішнього впливу.

Зазначений висновок грунтується на тому, що на початку 21 століття у США та розвинутих країнах Європи ввели у вжиток тезу про міжнародну інформаційну безпеку, визнавши, що незахищеність інформаційних ресурсів становить загрозу всьому світу. При цьому на Заході під цим розуміють стан, що забезпечується загальновизнаними $\mathrm{i}$ спеціальними принципами та нормами міжнародного права, який включає порушення міжнародного миру і безпеки у сфері інформації та комунікації як окремих держав, так i світового співтовариства в цілому [1].

Виходячи $з$ цього та враховуючи сучасні проблеми, що склалися в Україні у зв'язку з гідридною війною РФ та масовим використанням «інформаційної зброї» $з$ деструктивними проросійськими наративами та застосуванням проти Української держави «інформаційного тероризму» [2], слід визнати, що їх вирішен- ня неможливе без урахування позитивного досвіду забезпечення інформаційної безпеки країн НАТО, зокрема, на прикладі США - як одного із фундаторів цього Північноатлантичного блоку.

Таким чином, у наявності складна прикладна проблема, яка має бути вирішена, у т. ч. на науковому рівні.

Постановка завдання. Виходячи $з$ цього, метою даної наукової статті $є$ обгрунтування необхідності створення та розбудови в Україні ефективної системи забезпечення інформаційної безпеки держави за зразком такої країни НАТО, як США. А головним завданням - розробка науково обгрунтованих висновків на підставі аналізу апробованого зарубіжного досвіду з означеної проблематики, спрямованих на усунення та нейтралізацію детермінант, які негативно впливають на забезпечення інформаційної безпеки України.

Аналіз останніх досліджень та публікацій. Вивчення наукових, навчально-методичних та інших джерел, а також аналіз існуючих нормативно-правових актів США у сфері захисту національної безпеки показало, що цією проблематикою активно та продуктивно займаються такі вчені, як: Р. О.Банк, О.А. Баранов, В. М. Богуш, О. Ю. Бусол, I. O. Василюшко, Н. М. Волошина, К. С. Герасименко, О О. Грицун, Т. В. Збирак, О. Г. Колб, Б. А. Кормич, Л. В. Лабенко, О. В. Литвиненко, В. А.Ліпкан, А. М. Митко, А. Ю. Нашинець-Наумова, Т.С. Перун, М. М. Присяжнюк, Т. Ю. Ткачук, В. О. Шамрай та ін.

Зазначену тематику дослідження також дослоіджують вітчиз- 
няні та зарубіжні журналісти, що працюють у сфері аналітичної та прогностичної журналістики (Жигалкін Ю., Довгопол Я., США [3; 13] та ін.). Поряд із тим, постійна зміна негативних інформаційних приводів та провокацій, деструктивних нарати0вів зі сторони РФ тощо спонукає системно аналізувати відкриті джерела та відслідковувати, як на них реагують інформаційні сектори США та інших держав HATO і ЄC у питаннях модернізації та подальшої розбудови національних систем забезпечення інформаційної безпеки.

Виклад основного матеріалу Інформаційну безпеку та інформаційне домінування сповна можна назвати ключовими напрямами економіко-технологічного, наукововиробничого та військовополітичного лідерства США у світі. Парадоксально, але особливістю «спадковості» політики захисту інформаційної безпеки в США є їі фактична відсутність, тобто кожна нова президентська адміністрація пропонувала та реалізовувала свої тактичні і стратегічні дії. Це пояснюється тим, що інформаційна політика за своєю природою виникає на основі стратегії національної безпеки, військової доктрини, зовнішньополітичної доктрини, а вони істотно різняться у впровадженні політичних курсів різних президентів. Разом із тим, системний аналіз помилок, застереження опонентів і загальна критична оцінка кроків і дій влади в цій сфері зумовлює поступальний рух і лідерство США у вибудові чіткої та збалансованої у відповідності до нових викликів і вимог часу системи забезпечення інформаційної безпеки держави.

Як показали результати даного дослідження, правову основу забез- печення інформаційної безпеки, завдяки якій можна скласти уявлення про загальну державну політику США, становлять як федеральні закони, так і закони окремих штатів. Це насамперед - ключові закони «Про свободу інформації» (1967 р.), «Про висвітлення діяльності уряду», «Про охорону особистих таємниць», «Про таємницю» (1974р.), «Про право на фінансову таємницю» (1978 р.), «Про доступ до інформації про діяльність ЦРУ» (1984р.), «Про комп'ютерне шахрайство та зловживання» (1986 р.), «Про безпеку комп'ютерних систем» (1987 р.), «Про інформаційну безпеку», «Про удосконалення інформаційної безпеки» (1997р.) [4].

Національна політика США в галузі захисту інформації формується Агентством національної безпеки (далі - АНБ), а найважливіші стратегічні питання інформаційної безпеки розглядаються Радою національної безпеки з виданням директив президента США, серед яких: PD/NSC-24 «Політика в галузі захисту систем зв'язку» (1977р.), у якій уперше наголошено на необхідності захисту важливої несекретної інформації для забезпечення національної безпеки; «Національна політика США в галузі безпеки систем зв'язку в автоматизованих інформаційних системах» (1984 р.). Цією директивою на АНБ поклали функції із захисту інформації та контролю за безпекою як на каналах зв'язку, так і в обчислювальній та інформаційно-телекомунікаційній системах, відповідальність за сертифікацію технологій, систем і устаткування захисту інформації в цих системах, а також ліцензування діяльності в галузі захисту інформації. 
Так видається, саме під впливом США, як показала практика, Генеральна Асамблея $00 \mathrm{H}$ ще у 2001 р. на 56-й сесії акцентувала увагу на понятті «інформаційна та мережева безпека», відзначаючи захист особистої інформації про відправників і

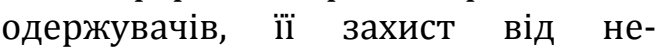
санкціонованих змін, несанкціонованого доступу до інформації та створення надійного джерела постачання обладнання, послуг та інформації. Інформаційна безпека в той час охоплювала захист інформації, що стосується військового потенціалу та інших аспектів національної безпеки [4]. Вже тоді передбачалося, що недостатній захист життєво важливих інформаційних ресурсів, інформаційних і телекомунікаційних систем несе загрозу міжнародній безпеці.

Зокрема, тенденцію щодо надання пріоритетної ролі інформаційній безпеці наочно демонструють такі резолюції Генеральної Асамблеї ООН, як: «Роль науки і техніки в контексті міжнародної безпеки, роззброєння та інших, пов'язаних 3 цим, сфер» № 53/576 (1998р.); «Досягнення у сфері інформатизації i телекомунікацій у контексті міжнародної безпеки» № 54/49 (1999 p.), № 55/28 (2000 p.), № 60/45 (2005 p.) [5].

Загалом державна політика США у сфері інформаційної безпеки, як вважає дослідник проблематики О. Ю. Бусол, пройшла тривалий еволюційний шлях, який складається із базових 4-х етапів: виникнення 1939-1947 рр.; становлення - 19471982 рр.; активний розвиток - 19832001 рр.; докорінне вдосконалення з 2001 р. і дотепер [4]. 3 приходом у 1981 р. президента США Р. Рейгана та його адміністрації в управлінні інформаційними ресурсами напрям інформаційної безпеки в урядовій політиці визначили як пріоритетний.

Так, уже в 1992 р. прийнято програми «Національна інформаційна політика» і «Глобальна інформаційна політика», що базувалася на п'яти ключових принципах: залучення приватних інвестицій, сприяння конкуренції; введення гнучких механізмів регулювання, які мають забезпечити пристосовування до швидких технологічних змін $\mathrm{i}$ ринкової конкуренції; надання відкритого доступу до існуючих мереж усім провайдерам і користувачам; забезпечення загальнодоступних інформаційних послуг; створення електронного уряду. Як наслідок, при Бібліотеці Конгресу США створено центральний депозитарій документів із проблем кібер-, медіа- та психотероризму задля моніторингу теорії i практики інформаційнопсихологічних впливів у сучасному світі, створення ефективної регіональної системи інформаційного протиборства та об'єднання зусиль держав-членів Організації американських держав у сфері інформаційної безпеки [6]. При цьому адміністрація США на офіційному рівні розглядає інформацію як стратегічний ресурс, що виникає в результаті оброблення даних за допомогою спеціалізованих систем аналізу.

Важливим у зв'язку з цим $\epsilon$ і те, що військово-політичне керівництво США та західних держав на початку 1990-х років надавало окремої уваги розвитку інформаційної технології, високо оцінюючи її потенційні можливості для досягнення військової переваги. Про це свідчить Директива США від 21 грудня 1992 р. «Інфор- 
маційна війна», в якій закріплені завдання щодо необхідності всебічного обліку інформаційних ресурсів при організації планування i функціонування систем управління в інтересах підвищення ефективності військ в умовах протидії супротивнику. Складовими концепту «інформаційна війна», на думку авторів його розробки, є: оперативна безпека, введення супротивника в оману, психологічні операції, електронна війна i вогневе знищення, що здійснюються в комплексі 3 глибокою та всебічною розвідкою як для дезорганізації системи управління противника, так і для захисту власної системи управління під час бойових дій. Інформацію, що циркулює в системі управління, розглядають як пріоритетний об'єкт впливу і захисту. Більше того, для військового відомства США, що використовує декілька сотень різних інформаційних систем і мереж, питання інформаційної безпеки фактично прирівнюється до питань військової безпеки [7].

У присвячених США статтях учених та науковців із цієї проблематики найчастіше зустрічається таке визначення поняття «інформаційні військові дій»: це - дії, вжиті для досягнення інформаційної переваги в інтересах національної військової стратегії; дії, що здійснюють шляхом впливу на інформацію та інформаційні системи противника при одночасному захисті власної інформації та своїх інформаційних систем [8].

Цікавим $\epsilon$ той факт, що в березні 2001 р. Президент США Дж. Буш, виступаючи в штабквартирі ЦРУ, вказав на основні загрози національній безпеці США. На другому місці після тероризму в цьому переліку значиться інформаційна війна, уже за нею розповсюдження зброї масового ураження та засобів їі доставки. В цьому ж 2001 р. вперше озвучено тезу про міжнародну інформаційну безпеку, що забезпечується загальновизнаними і спеціальними принципами i нормами міжнародного права. Порушення цього стану включає порушення міжнародного миру та безпеки як окремих держав, так i світового співтовариства в цілому у сфері інформації та комунікації [1, c. 30-31].

Варто зауважити, що першочергова складова міждержавних відносин в інформаційній сфері полягає у необхідності забезпечення належного та стійкого балансу між правоохоронними інтересами і повагою до основних прав і свобод людини. Цю складову в доктрині міжнародного права визначають як кримінальний аспект міжнародної інформаційної безпеки. Відповідно, при цьому й використовують термінологію: «транскордонна комп'ютерна злочинність», «кіберзлочинність», «комп'ютерні злочини», «високотехнологічні злочини», «злочини у сфері комп'ютерної інформації», «кіберзлочини», «інформаційні злочини» тощо) [9].

У 2009 р., висловлюючи свої зауваги щодо безпеки національної кіберінфраструктури, Президент США Б. Обама робить висновок про те, що кіберзагрози $€$ одними 3 найбільш серйозних викликів економічній і національній безпеці, 3 яким зіткнулася нація. 3 огляду на це, він оголосив цифрову інфраструктуру США стратегічною національною цінністю, а її захист - 
національним пріоритетом, у якому основні заходи в цій сфері спрямовані на розроблення ефективної стратегії забезпечення безпеки інформаційних і комунікаційних мереж; розроблення систем запобігання й реагування на кібератаки; посилення партнерства держави і приватного сектора; збільшення інвестицій в інноваційні технології та розгортання масштабної національної кампанії щодо посилення готовності суспільства до протидії кіберзагрозам [10].

У такому ж контексті й вибудовувалася нормативно-правова доктрина США 3 означеного питання. Показовою у цьому сенсі $\epsilon$ Ініціатива із загальної національної кібербезпеки Ради національної безпеки США 2010 р., що $€$ складовою частиною Воєнної доктрини США та яка містить 12 положень щодо реалізації захисту держави та Білого дому від кібератак. Відповідно до цього документу, в США створено єдину захищену федеральну мережу, доступ до якої чітко контролюється. Крім того, ініціатива передбачає об'єднання всіх наявних у США центрів оперативного реагування на кіберзлочини задля проведення глибокого аналізу хакерських атак. Також з метою протидії іноземним кібершпигунам документ передбачає створення підрозділів кіберконтррозвідки $\mathrm{y}$ державних органах США, зокрема для захисту секретних внутрішніх мереж Міноборони США від терористичних атак. У свою чергу, в Стратегії кібербезпеки США (2011р.) закріпили право держави вживати заходи у відповідь на хакерські атаки, які у відповідних умовах можуть розглядатися США як оголошення війни. Так, Закон CISPA (Cyber
Intelliggence Sharring and Protection Act) (2012 p.) дає змогу уряду США та недержавним органам за наявності підозри про вчинення кіберзлочину мати доступ до конфіденційної інформації користувачів приватних фірм [4].

Важливе місце у системі нормативно-правових документів США, що регулюють безпеку кіберпростоpy, займають такі, як: Національна стратегія безпечного кіберпростору (2003 р.) [11], Огляд політики кібербезпеки (2009 р.), Міжнародна стратегія для кіберпростору (2011р.), Наказ президента США «Щодо проекту Стратегії покращення кібербезпеки критично важливих об'єктів інфраструктури (2013р.), проект Стратегії покращення кібербезпеки критично важливих об'єктів інфраструктури (2014р.), Закон з кібербезпеки та обміну інформацією (2015 р.), Національна стратегія безпеки (2015 р.), Стратегія кібербезпеки департаменту оборони (2015р.) тощо. У зазначених нормативноправових актах закріплені дії зі знешкодження та протистояння атакам у національному інформаційному просторі, а також визначені види загроз і обов'язки захисту кіберпростору для різних спеціалізованих держустанов. Крім цього, зазначені документи визначають умови для обміну даними 3 протидії кіберзагрозам, прогнозування ризиків, співробітництва 3 іншими державами 3 проблем кібертероризму та підвищення кваліфікації фахівців із протидії цим злочинам. Окремо акцентується увага на залученні до протидії тероризму приватних установ і громадських організацій, а також використання можливостей освітніх і наукових установ при про- 
веденні досліджень із забезпечення безпеки національного кіберпростоpy [12].

Проведений аналіз змісту нормативно-правових джерел, що стосуються вирішення проблем, пов'язаних із інформаційними війнами, дає змогу констатувати, що за останні десятиліття у США сформувалася чітка й доволі ефективна система забезпечення інформаційної безпеки, що вибудовувалася в декілька етапів. Дослідники сходяться на думці, що пороговими серед них можна вважати декілька. У 1981 р. інформаційна безпека стає пріоритетом урядової політики США У 1987 р. встановлено нову категорію інформації - «несекретна, але важлива з погляду національної безпеки». У 1992 р. інформаційна безпека зводиться в ранг національної інформаційної політики, особливу увагу звернено на глобальну інформаційну політику, а в обігу уряду США з'являється поняття «інформаційна війна». У 2001 р. формується поняття «міжнародна інформаційна безпека» i визнається, що незахищеність інформаційних ресурсів становить загрозу всьому світу. Поняття «інформаційна війна» в адміністрації президента за пріоритетністю - на другому місці (після тероризму). У 2009 р. цифрову інфраструктуру США оголошують стратегічною національною цінністю, а її захист національним пріоритетом. У 2011 р. хакерські атаки прирівнюють до оголошення війни. 32015 р. законодавче регулювання кіберпростору виходить на перший план політики США. Хоча подекуди й надалі мають місце факти недооцінки зовнішніх ризиків i загроз у сфері інформаційної безпеки (особливо при президенстві Д. Трампа [13], американське суспільство на них активно реагує і відносно швидко усуває. Саме тому ця система постійно розвивається та еволюціонує, а США продовжує залишатися світовим лідером у розбудові ефективної системи забезпечення інформаційної безпеки держави.

Висновки. Таким чином, американський досвід державної політики у сфері інформаційної безпеки можна визнати вкрай важливим для української зовнішньої i внутрішньої політики 3 означеної проблематики. При цьому найціннішим є дієвий підхід до регулювання ринку інформаційних технологій в умовах ринкової економіки, враховуючи, що нині Україна $\epsilon$ одним із лідерів у світі з підготовки висококваліфікованих IT-фахівців та одним із основних постачальників «інтелекту» відповідного напряму за кордон.

Більш того, зважаючи на те, що США мають величезний досвід застосування інформаційних технологій у всіх сферах життєдіяльності суспільства, особливо важливим, в умовах проведення Україною урядових заходів у відповідь на зовнішню агресію з боку РФ, є американський досвід використання інформаційних технологій для створення систем зв'язку і військового керування, а також високоточного озброєння, що дасть змогу значно ефективніше запобігати та протидіяти посяганням інформаційного характеру на національну безпеку нашої держави. 


\section{Список використаних джерел}

1. Грицун О.О. Міжнародно-правове забезпечення міжнародної інформаційної безпеки. Дис. на здоб. наук, ступеня к.ю.н., спец. 12.00.11.КНУ імені Тараса Шевченка. Київ, 2016. 233 с.

2. Колб О. Г., Пирожик О. В., Дучимінська Л. М., Колб Р. О., Кухарчук Д. С.. Про зміст і соціально-правову природу деяких джерел, що посягають на національну безпеку України. Ділектологія: монографія. Під заг. ред. І. М. Копотуна, С. В. Пєткова, P. Polian. Куновіце: Академія ГУСПОЛ: 2020, Т. 3. С. 78-115.

3. Жигалкин Ю. Доказательства вмешательства России в выборы президента США. Радіо Свобода. URL: https://www.svoboda.org/a/usa-russia-indictment/ 29044968.html (дата звернення: 03.06.2021).

4. Бусол О. Ю. Інформаційна безпека США: законодавче регулювання та перспективи співпраці для України. Центр досліджень соціальних комунікацій НБУВ. URL: http://nbuviap.gov.ua/index.php?option=com_content\&view=article\&id=2988:informatsijn a-bezpeka-ssha-zakonodavche-regulyuvannya-ta-perspektivi-spivpratsi-dlya-

ukrajini\&catid=8\&Itemid=350 (дата звернення: 30.05.2021).

5. Developments in the field of information and telecommunications in the context of international security. Resolution adopted by the General Assembly on 8 December 2005. № 60/45. URL: https://documents-dds-ny.un.org/doc/UNDOC/GEN/N05/ 490/30/PDF/N0549030.pdf?OpenElement (дата звернення: 02.06.2021).

6. National Security Strategy of the United States of America. Washington. 2010, may. 52 p. White House. URL: https://www.archives.gov/presidential-libraries/archivedwebsites (дата звернення: 01.06.2021).

7. Шамрай В. О. Інформаційна безпека як складова національної безпеки України. Центр досліджень проблем комп'ютерної злочинності. URL: http://www.crime-research.ru/library/Shamray.htm (дата звернення: 02.06.2021).

8. Баранов А. А. Информационный суверенитет или информационная безопасность. Нац. безпека і оборона. 2001. № 1. С. 70-76.

9. Забара I. М. Інститут міжнародної інформаційної безпеки: правові аспекти. Правова інформатика. 2014. № 1 (41). С. 64-71.

10. Statement by the President on the White House Organization for Homeland Security. URL: https://obamawhitehouse.archives.gov/the-press-office/statement-presidentwhite-house-organization-homeland-security-and-counterterrorism (дата звернення: 04.06.2021).

11. National Strategy to Secure Cyberspace. February 2003. URL: https://www.uscert.gov/sites/default/files/publications/cyberspace_strategy.pdf (дата звернення: 05.06.2021).

12. US-CERT: Understanding Hidden Threats: Rootkits and Botnets. URL: https://www.us-cert.gov/ncas/tips (дата звернення: 06.06.2021).

13. Довгопол Я. Що і як сказав Трамп Конгресу? Російське питання. Укрінформ. URL: $\quad$ https://www.ukrinform.ua/rubric-world/2184991-so-i-ak-skazav-trampkongresu.html (дата звернення: 03.06.2021).

\section{References}

Gritsun, 0. 0. (2016). International legal support of international information security. (Dis. Theses). Taras Shevchenko National University of Kyiv. Kyiv.

Kolb, O. G., Pirozhik, O. V., Duchyminskaya, L. M., Kolb, P. O., Kukharchuk, D. S. (2020). Dilectology. Under the general. ed. I. M. Kopotun, S. V. Petkova, P. Polian. Kunowice: HUSPOL Academy. Vol. 3. 
Busol, O.Y. US information security: legislation and prospects for cooperation for Ukraine. Vernadsky National Library of Ukraine Center for Social Communications Research. URL: $\quad$ http://nbuviap.gov.ua/index.php?option=com_content\&view= article\&id=2988:informatsijna-bezpeka-ssha-zakonodavche-regulyuvannya-ta-perspektivispivpratsi-dlya-ukrajini\&catid=8\&Itemid=350:30.05.2021).

Shamray, V. O. Information security as a component of national security of Ukraine. Computer Crime Research Center. URL: http://www.crimeresearch.ru/library/Shamray.htm (access date: 02.06.2021).

Baranov, A. A. (2001). Information sovereignty or information security. Nat. security and defense, 1, 70-76.

Zabara, I. M. (2014). Institute of International Information Security: legal aspects. Legal informatics, 1 (41), 64-71.

Dovgopol, J. What and how did Trump say to Congress? The Russian question. Ukrinform. URL: https://www.ukrinform.ua/rubric-world/2184991-so-i-ak-skazav-trampkongresu.html (access date: 03.06.2021).

O. Pyrozhyk, adviser to the first deputy chairman of the Volyn Regional Council, deputy of the Volyn Regional Council

ORCID: 0000-0001-5793-7433

\section{On the need for Ukraine to use the positive experience of the United States in building an information security system}

The article considers issues related to the need to create an effective national system of information security in Ukraine, following the example of a such NATO country as the United States. In particular, the US regulations in this area of public relations and positive experience on these issues are analyzed, as well as scientifically sound measures to address these issues.

In particular, the article examines the evolution of the American system of information security of the state through the prism of the main threats to national security. The main stages of the evolution of this system are traced, as a result of which "information warfare" and "information security" in the USA become the second among all the threats to the national security after the terrorism, outpacing the proliferation of weapons of mass destruction and their means of delivery, the threshold stages of an effective information security system, which has been formed in the United States in recent decades, are determined.

The study also notes that back in 2001 in the United States for the first time announced the thesis of international information security - as a condition provided by generally accepted and special principles and norms of international law, which includes violations of international peace and security of individual states and the world community in general in the sphere of information and communication.

It should be noted that the main external factor that determines the evolution of the information security system in the United States is the aggressive influences and destructive actions of the Russian Federation, which consist in systematic encroachment on information security and determine the need for active counteracting and encroaching on these encroachments. 
For Ukraine, which has been waging a hybrid war with Russia for seven years, including information war, the presence and relevance of these problems - is obvious. Therefore, the experience of NATO countries, and the United States in particular, in this area is particularly valuable, useful and largely applicable in the formation of Ukraine's own effective model of information security and its development.

Keywords: information security; information war; National security; system; provision; cybersecurity. 